DOI https://doi.org/10.18551/rjoas.2017-11.25

\title{
THE IMPORTANCE OF BUREAUCRACY STRUCTURE FACTOR IN THE IMPLEMENTATION OF MINIMUM STANDARD OF HEALTH SERVICE IN CENTRAL JAVA PROVINCE, INDONESIA
}

\author{
Mardianti N.I.* \\ Master's Degree Program in Public Administrative Science, \\ Faculty of Administrative Science, University of Brawijaya, Indonesia \\ Hakim A., Hariswanto A. \\ Faculty of Administrative Science, University of Brawijaya, Indonesia \\ *E-mail: noorvita81@gmail.com
}

\begin{abstract}
This paper examines the phenomenon of incompatibility of the institutional structure of Regional Public Hospital which causes the disruption of the achievement of Minimum Service Standards (MSS) indicator in the health sector, especially maternal health in the Provincial Government of Central Java. In Central Java, the largest number of maternal mortality rate was in the hospital in 2015 amounted to $85.71 \%$. Meanwhile, the coverage rate of delivery assisted by health personnel in accordance with the indicator of MSS is $98.09 \%$. In 2015 , Central Java is the province with the second highest national of maternal mortality rate case amounted to 619 cases. The Provincial Government as the coordinator of MSS implementation in the region through the Bureau of Pemotda and the Cooperation of Regional Secretariat of Central Java has a significant role in the successful implementation of the Regulation of Minister of Health 43/2016 on MSS in Health Sector. In which MSS has a function to observe the implementation of health program in the region. This research uses a qualitative approach, the type of research is a case study and interactive model analysis from Miles, Huberman, and Saldana. The results of the analysis show that the implementation process of the policy in Bureau of Pemotda and the Cooperation of Regional Secretariat of Central Java has not run well obstructed by bureaucratic structure factor. It can be seen from the unfulfilled policy objective which is to provide convenience to local government in the preparation of planning document on the achievement of health MSS indicator. Although health MSS is achieved, it will not be able to reduce the maternal mortality rate.
\end{abstract}

\section{KEY WORDS}

Bureaucracy structure, minimum service standards, health.

Public Administration is an important instrument in realizing the goals of the state. Furthermore, the process in the administration public will result in public policy products. The RPJMD of Central Java Province in 2013-2018 shows that the health is a major problem, in accordance with the data of Central Java Health Profile (2015: 12-18) which indicates high maternal mortality rate amounted to 111.16 per 100,000 of live birth $(\mathrm{KH})$ with 619 cases in 2015 and the second highest nationwide (Kemenkes, 2016). Meanwhile, the achievement result of health MSS in the same year obtaining the result that the coverage of delivery assisted by health personnel was high enough to reduce the maternal mortality rate. The phenomenon in the Provincial and Regency/Municipal Government is that the implementation of Permenkes 43/2016 on MSS of Health Sector is partly integrated into planning and budgeting documents, but not in accordance with the stages of achievement of MSS indicator. Thus, the maternal health services are not optimal.

The frontliner of the MSS implementation in the region should not only involve the community health center but also the Department of Health Affairs, Hospital, and other health service providers. In addition to the institution of technical function, the optimal coordination 
with the institution of coordination function namely Bureau of Pemotda and the Cooperation as the coordinator of the implementation of health MSS in the region. In accordance with Government Regulation 18/2016 on Regional Government Agency article 43 states that "there is Regency/City of Technical Implementation Unit (of a government body) (UPTD) in health sector in the form of Regency/City of Regional Public Hospital and community health center as the organizational unit with functional nature and service unit working professionally". Thus, Hospital as the functional implementer of health affair works under the Department of Health Affairs. Where previously the status of the Hospital is parallel to the Department of Health Affairs as a Regional Technical Institute that is directly responsible to the Regional Head.

Under the parallel condition alone cannot overcome the problem of maternal mortality, where the highest maternal mortality occurred in the Hospital amounted to $85.71 \%$ in 2015 (ekib.dinkesjatengprov.go.id, 2015). Furthermore, with the institutional change where the Hospital has to be under the Department of Health Affairs affecting the budgeting mechanism. It is well known how complex the of structural needs and budgeting of a Hospital. According to the data of Health BPJS of 2014, the childbirth was ranked on number 2 from the top 10 inpatient cases nationally and ranked on number 4 of top 10 inpatient claims that requires a substantial cost. This shows the significant role of the Hospital as the determinant of the successful achievement of health MSS target, especially maternal health indicator. The management of the institutional structure has the function to eliminate the power in one health affairs in the region, thus coordination of the implementation of health affairs in accordance with the Regulation of the Minister of Health 43/2016 on MSS of health sector can be achieved.

This study discusses the implementation process of MSS based on Regulation of the Minister of Health 43/2016 on MSS of health sector at the coordination function that is in Bureau of Pemotda and the Cooperation of Regional Secretariat of Central Java Province as the coordinator of the implementation and achievement of MSS in the region. "Implementation is essentially an effort to understand what should happen after the program in the policy implemented" (Sugandi, 2011: 88), thus the implementation plays an important role in the process that occurs between the policy and its purpose. There are two research questions in this study. Firstly, how is the implementation process of Regulation of the Minister of Health 43/2016 on MSS of Health Sector in Bureau of Pemotda and the Cooperation of Regional Secretariat of Central Java? Second, what are the inhibiting factors on the process Implementation of the policy?

\section{LITERATURE REVIEW}

"The journey of public administration cannot be separated from politic as part of the public dynamic" (Sugandi, 2011: 1). Dimock and Fox (1983) in (Ibrahim, 2013: 15) state that "Public administration is produced of good service designed to serve the needs of citizencostumers". This is in accordance with the principle of policy concerning health as the service of basic needs for the society. In Indonesia, its implementation must be guided by MSS of health sector set by the Central Government in accordance with Article 18 of Law 23/2014 on Regional Government. Subsequently followed up by the Ministry of Health, through Minister of Health Regulation 43/2016 on MSS of Health Sector. Graham and Hays (1986) in (Ibrahim, 2013: 15) mention "In ordinary usage, public administration is a generic expression for the whole bundle of activities that are involved in the establishment and implementation of public policy". In which the public administration is the whole activity related to the formation and implementation of public policy. Similarly, for the preparation of policy on MSS of the health sector in Indonesia, such activities are part of the public administration up to its implementation.

In accordance with Anderson quoted by Wahab, "formulating the policy as a step of action that is intentionally done by an actor or a number of actors with regard to the existence of a problem or a particular problem that is currently facing" (Wahab, 2004: 3). "The uniqueness of public administration lies on the foundation of the science of administration 
itself, namely politic and public policy. The uniqueness of decision-making that follows the direction of power" (Sugandi, 2011: 65). Anderson (1987: 22-42) says that "public policies are developed by governmental bodies and official," it can be interpreted that public policy is "policies developed by government agencies and officials".

Dye (2011) in Nugroho (2017: 539), attributes the notion of policy to the process of policy analysis, namely "a series of intellectual activities undertaken in the policy-making process and visualized as a series of interdependent stages arranged according to time". The arrangement of the policy process, as shown below:

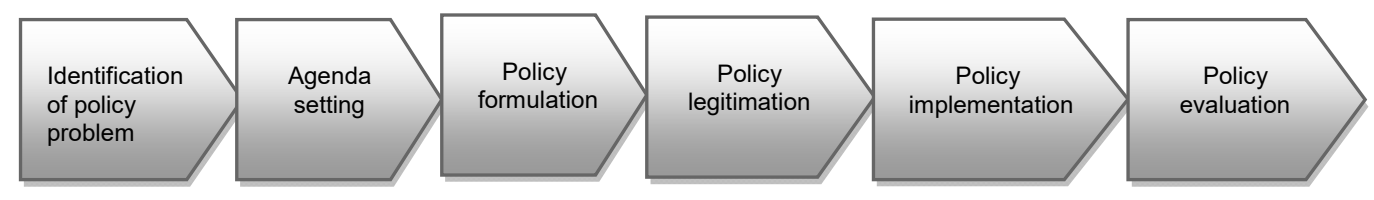

Figure 1 - Dye Policy Process

Model is the tool or concept created to facilitate us in reviewing the public policy. Unlike the theory in which its validity has been proven through empirical testing, although the model has not yet become the empirical theory, the model can still be used as the guidance in the research (Brodbeck, 1959: 374) in (Winarno, 2016: 35). "Implementation is a crucial stage in the policy process" (Ripley and Franklin, 1982, in Tarigan, 2000: 14; Wibawa et al., 1994: 15). This is in accordance with the statement of Edwards III (1984: 1) that "without effective implementation, the decision of the policymaker will not be carried out properly". According to Sugandi (2011: 88) "it is essentially an effort to understand what should happen after the program in the policy implemented., so all parties should have the same opinion, there should not be a difference in the perception to achieve the goals". Regulation of the Minister of State for the Empowerment of State Apparatus Number PER/04/M.PAN/4/2007 concerning General Guidelines for Formulation, Implementation, Performance Evaluation, and Revision of Public Policy in the Environment of Central and Regional Government Institutions, in the general sense stating that the policy implementation is "the activity or process of implementation or application of the established public policy".

George Edward III (1980: 1) asserts that the main problem of public administration is the lack of attention to the implementation. The policy implementation model developed by George C. Edward III has a top-down perspective. Edward III (in Agustino, 2008: 149-154) named his public policy implementation model with Direct and Indirect Impact on Implementation. Edward requires four key issues for effective implementation of the policy, "communication, resource, disposition or attitudes, and bureaucratic structures". Model is the tool or concept created to facilitate us in reviewing the public policy:

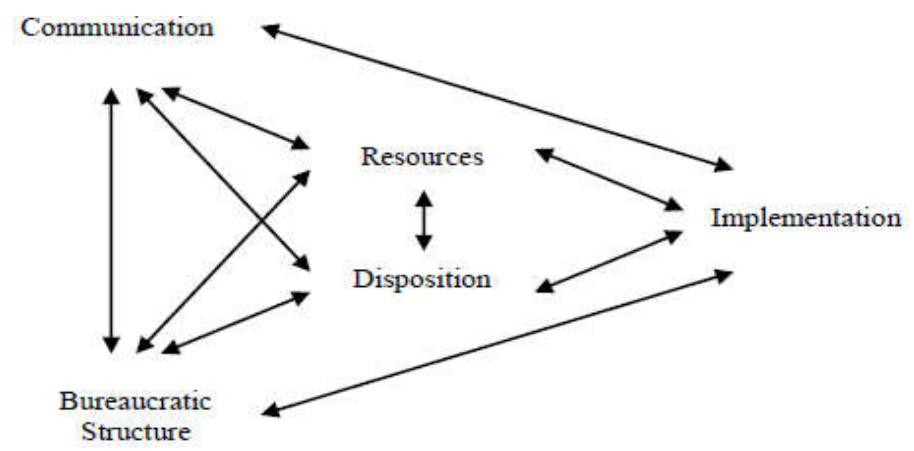

Figure 2 - Edward III Policy Implementation Model

Some policy experts have their own opinion on the determinant of the success of a policy implementation. One of the models has the character of policy implementation identified to have the pattern of top-down, bottom-up, enforced mechanism dan market mechanism. The implementation of the top-down model is "the process where its 
implementation from the vertical and centralized side following the bureaucratic hierarchy" (Hill, 2009) in Yuliani (2011: 5). "Formulation of the policy is made by the high level of the state institution, the policy implementation and evaluation are conducted by the implementer of institutional bureaucracy" Sabatier, 1986) in Yuliani (2011: 5). According to Berman (1980) and Hill (2009) in Yuliani (2011: 12-13), the weakness of the top-down model is that "the complex social reality and its own policy affecting many sectors and involving organizations, actors, and bureaucratic level with different goals, interests, and resources ". It proves that it is impossible for one policy to succeed if it is only implemented by a single government agency.

According to Nugroho (2017: 754) enforced mechanism: command and control are to prioritize the importance of public institution as the sole institution with the power to monopolize on the forced mechanism in the country without incentive mechanism for the implementation, but there is sanction for those who refuse to implement or violate it. In line with the definition in the Complete Dictionary of Law (2012: 56), the enforced mechanism is supervised by the scheme of making rules and conducting inherent supervision. This mechanism will be less effective if it is lacking supervision and availability of resources in the (Aziz, 2010: 63). Meanwhile, the model of market mechanism: economic incentives according to Nugroho (2017: 754) is a model that prioritizes incentive mechanism for those who implement it but no sanction or incentive will be given to those who do not implement it.

\section{METHODS OF RESEARCH}

The research method used in this research is qualitative, where the researcher has the nature of emic in collecting data, based on the perspective of the data source not the perspective of the researcher (Sugiyono, 2015: 6). The type of the research is a case study. Arikunto (2002) in (Gunawan, 2015: 116) state that "the case study method is one of the kinds of descriptive approach, a detailed, in-depth incentive study of a particular organism (individual), institution or a certain symptom with a limited area or subject ". Data were collected through interview, observation, and documentation. This case study is based on existing theories. The position of utilization of existing theory is intended to determine the direction and focus of the research (Gunawan, 2015: 123).

The data analysis technique of this research is interactive Model of Miles, Huberman, and Saldana (2014), "the activity of data analysis consisting of three activities path that happened simultaneously namely: condensation data, data presentation, and conclusion/verification". The data found are tested by analyzing and clarifying them with the model implementation of George C Edward III, top-down, enforced mechanism, and market mechanism. Afterwards, validity testing is done with the field source and method, as well as the discussion. The conclusion is interpreted from verification tailored to the data and studies obtained during the research.

\section{RESULTS AND DISCUSSION}

The implementation of MSS of health sector through Regulation of the Minister of Health 43/2016 is a top-down implementation. In accordance with the implementation model of George C Edward III, one of the characteristics of the top-down model is the National Strategic Program policy set by the Central Government, namely the Ministry of Home Affairs and the Ministry of Health. Containing clear guidelines: standard, target, and standard rule, as in appendix Regulation of the Minister of Health 43/2016. Meanwhile, the implementation process of Regulation of the Minister of Health 43/2016 on MSS of health sector has not reached its objective. The reason is that it has not been able to facilitate for the region in making the planning of achieved target of MSS in the health sector in the Regency/City in its planning document, either in the Bureau of Pemotda and the Cooperation, Department of Health Affairs, Community Health Center and Hospital.

This MSS of health sector implements the enforced mechanism and market mechanism model. Where there will be incentive/reward from Special Allocation Fund of 
National State Budget (in accordance with the attachment of Regulation of the Minister of Health 43/2016) for those who implement it, and there will be sanction (according to the Article 68 of Law 23/2014 on Regional Government) for those who do not implement, violate or not reach the target. Limited surveillance and resource systems such as the location of the case study, resulting the Province and Regency/City in the Central Java face many difficulties in arranging the target and achievement of MSS in the health sector in the case of its planning document. Target and achievement that have been integrated into the planning document cannot leverage the achievement of MSS of the health sector. Where appropriate, with a top-down policy implementation model, the Central Government only uses forced mechanism. Health is the basic rights that should be provided by the government for its citizen, in which it does not need an incentive in its implementation. On the other hand, the sanction should be given to the local government that has not been providing health services to their citizen optimally. To this day sanction has not been implemented well. Using two mechanisms at once has caused the implementation process of MSS of health sector less effective.

Table 1 - Data Presentation

\begin{tabular}{|c|c|c|}
\hline Focus & Data source & Result \\
\hline Communication & \multirow{4}{*}{$\begin{array}{l}\text { Interview: Coordination } \\
\text { Function (Bureau of } \\
\text { Pemotda and the } \\
\text { Cooperation) and } \\
\text { Technical Function } \\
\text { (Provincial Department } \\
\text { of Health Affairs and } \\
\text { Tugurejo Hospital); } \\
\text { Observation; and } \\
\text { Document }\end{array}$} & $\begin{array}{l}\text { Socialization, training has not been able to improve the understanding of human } \\
\text { resources in the structure of coordination function and technical function; } \\
\text { The difference of unit or coordination of MSS between Regency/City and } \\
\text { between Province and Regency/City }\end{array}$ \\
\hline Resources & & $\begin{array}{l}\text { Lack of the number and quality of human resources where it keeps changing } \\
\text { both in coordination and technical function; } \\
\text { Development and information are not evenly distributed; } \\
\text { Lack of Health Equipment for Maternal's Health; } \\
\text { Health budget allocation is still below } 10 \% \text {. }\end{array}$ \\
\hline Disposition & & $\begin{array}{l}\text { Appointment of bureaucrats has not adjusted to the professional ability of its } \\
\text { officials; } \\
\text { Reward and punishment are not executed for the achievement of MSS. }\end{array}$ \\
\hline $\begin{array}{l}\text { Bureaucratic } \\
\text { Structure }\end{array}$ & & $\begin{array}{l}\text { MSS team has not worked according to tupoksi: no follow-up on technical } \\
\text { function; } \\
\text { There is no SOP on MSS of health sector; } \\
\text { Fragmentation occurs: there is no cooperation between institutions of } \\
\text { coordination and technical function. }\end{array}$ \\
\hline
\end{tabular}

Communication, effective implementation requires not only clear communication but also consistent communication. A good transmission process with the inconsistent order will cause confusion among the implementers. The detailed and complex requirements of MSS complicate the implementing apparatus and the field apparatus which generate large budget projections. This will eventually cause the policy not optimally implemented. Furthermore, the SPM and Provincial/District Officers are not synchronized complicating the delivery of the information regarding the Regulation of the Minister of Health 43/2016 clearly, appropriately with mutual understanding. Transmission issues at Bureau of Pemotda and the Cooperation occur when the policy to be implemented must go through a layered structure of the bureaucratic without available adequate communication channels (resources). In the implementation of the MSS, the implementer is divided into technical and coordination function. The communication between these two functions (Bureau of Pemotda and the Cooperation, Department of Health Affairs and Hospital) has not been built comprehensively.

Resources, the ability of the Bureau of Pemotda and the Cooperation in implementing the policy requires resources, namely: 1) staff, which is still very lack of staff in Subbag Urpem and MSS of Bureau of Pemotda and Cooperation in terms of quality, quantity and the presence of turnover of the highly dynamic apparatus; 2) information, Regulation of the Minister of Health 43/2016 has clearly stated as well as the Operational manual and Technical manual; 3) authority, this has not been used maximally by Bureau of Pemotda and the Cooperation as coordinator of the MSS implementation; and 4) facilities, it is not yet available with sufficient health financing, which is used to fund facilities, infrastructure, and health equipment as well as internet networks. Including the financing through health care providers, where hospitalization cost is usually very high. 
Disposition, implementation is determined by the disposition according to Goerge C.Edward III (in Agustino, 2008: 152-154), namely the recruitment of official and incentive. Where incentive is one of the strategies for policy implementation to run according to policy objectives. Thus, when the reward in the form of incentive from the central government (DAK) is not executed resulting in the region only to report the achievements of MSS. The existence of structural changes both in institutional and apparatus, complicate its implementation. The placement of officials on certain structures must also be paid attention to the professional skill and professional skill of the official on the occupied position.

Bureaucracy Structure, the Implementation Team of MSS Achievement has not worked according to tupoksi: No follow-up from the preparation of MSS Team; There is no SOP, which regulates the MSS reporting, the performance of MSS staff and the coordination of MSS at the Provincial level; and there is no synergy cooperation between the coordination agency (Bureau of Pemotda and the Cooperation) and technical function (Department of Health Affairs and Provincial Hospital). Up to this day, they are only guided by the regulation of each Ministry which is very technical. The government should prepare the Standard Operating Procedures (SOP), both technical and non-technical (coordinative function). This leads to fragmentation or sectoral ego, in Central Java Province there is fragmentation between coordination function and technical function in which the coordination does not work at all. For example, the current condition between Hospital and Department of Health Affairs where the other has technical function constrained by the coordination due to the institutional change of the Hospital against the Department of Health Affairs. Not to mention the coordination with other coordination functions namely the planning and supervisory agencies. They maintain the function sector and deny the effort of policy coordination in the implementation of MSS health program. The worst consequence of bureaucratic fragmentation is inhibition of coordination. In fact, the top-down distribution of authority from the central government comes from different functions, namely Ministry of Home Affairs and Ministry of Health, thus to implement complex policy requires coordination. In general, greater coordination will reduce the possibility of successful implementation of Regulation of the Minister of Health 43/2016 on MSS in Health Sector.

The implementation of Regulation of the Minister of Health 43/2016 on MSS of Health Sector, the study case in Bureau of Pemotda and the Cooperation of Regional Secretariat of Central Java: communication in the coordinator institution and technical implementation of MSS achievement in health sector, lack of human resources and budget, appointment of bureaucratic officials professional and the absence of SOP in the coordination and technical implementation of MSS in health sector, causing fragmentation between coordination function and technical function. In the end, the implementation of MSS health will not succeed.

\section{CONCLUSION}

Implementation process of Regulation of the Minister of Health 43/2016 on MSS of Health Sector in Bureau of Pemotda and the Cooperation of Regional Secretariat of Central Java has not run well due to several inhibited factors such as: (1) there is no mutual understanding in the communication between coordinator institutions and technical implementer of MSS of health sector; (2) lack of human resources and budget; (3) appointment of bureaucrats has not adjusted to the professional ability of its officials; and

(4) there is no SOP in the coordination and technical implementation of MSS of health sector.

\section{REFERENCES}

1. Abdul Wahab, Solichin, 2002. Analisis Kebijaksanaan: Dari Formulasi ke Implementasi Kebijaksanaan Negara. Jakarta: Sinar Grafika.

2. Agustino, Leo, 2008. Dasar-Dasar Kebijakan Publik. Bandung: Alfabeta.

3. Aziz, Iwan J, 2010. Pembangunan Berkelanjutan: Peran Dan Kontribusi Emil Salim. Jakarta: Kepustakaan Populer Gramedia. 
4. Dinas Kesehatan Provinsi Jawa Tengah, 2015. Profil Kesehatan Provinsi Jawa Tengah Tahun 2015. Semarang.

5. Edward III, George C., 1980. Implementing Public Policy. USA: Conresinal Quartely Press.

6. Gunawan, Imam, 2015. Metode Penelitian Kualitatif Teori \& Praktik. Jakarta: Bumi Aksara.

7. Ibrahim, Amin, 2013. Pokok-Pokok Administrasi Publik Dan Implementasinya. Bandung: Refika Aditama.

8. Kementerian Kesehatan Republik Indonesia, 2016. Profil Kesehatan Indonesia Tahun 2015, Jakarta: Kementerian Kesehatan RI.

9. Kementerian Sekretariat Negara, t.t. Undang-undang No. 23 Tahun 2014 tentang Pemerintahan Daerah. Jakarta.

10. Peraturan Menteri Kesehatan No. 43 Tahun 2016 tentang Standar Pelayanan Minimal Bidang Kesehatan. Jakarta.

11. Maribun, Rocky, 2012. Kamus Hukum Lengkap: Mencakup Istilah HukumDanPerundangUndangan Terbaru. Jakarta: Visi Media.

12. Miles, Matthew B., A. Michael Huberman, dan Saldana, 2014. Qualitative Data Analysis: A Methods Sourcebook. SAGE Publication.

13. Moeloek, Nila Farid, 2016. Kebijakan Pembangunan Kesehatan, Rapat Kerja Kesehatan Nasional, Jakarta: 5 April 2016.

14. Nugroho, Riant D., 2017. Public Policy: Dinamika, Analisis Kebijakan, Manajemen Politik, Etika dan Kimia Kebijakan Publik. Jakarta; PT. Elex Media Komputindo.

15. Sugiyono, 2015. Metode Penelitian Kuantitatif, Kualitatif, Dan R \& D. Bandung: Alfabeta.

16. Winarno, Budi, 2016. Kebijakan Publik Era Globalisasi Teori, Proses dan Studi Kasus Komparatif. Yogyakarta: Center Of Academic Publishing Service.

17. Yuliani, Sri, 2011. Model Implementasi. Surakarta: FISIP UNS. 